\title{
部分壁体試験に基づく土壁のせん断力－変形角関係及び壁倍率の 推定方法と検証 \\ PREDICTION AND ITS VERIFICATION OF SHEAR FORCE-DEFORMATION RELATION AND BRACING UNIT MULTIPLIER FOR MUD WALLS BASED ON A PORTION -WALL TEST
}

\author{
岡本滋史 ${ }^{*}$, 澤田圭 ${ }^{* *}$, 村上雅英 ${ }^{* * *}$, 鈴木 有 ${ }^{* * *}$, 稲山正弘 ${ }^{* * * * *}$ \\ Shigefumi OKAMOTO, Kei SAWATA, Masahide MURAKAMI, \\ Tamotsu SUZUKI and Masahiro INAYAMA
}

\begin{abstract}
A portion-wall test method is presented in this paper to predict the shear performance of Japanese traditional mud walls based on their lateral load carrying mechanism. It was already clarified through our recent research that this mechanism consisted of the four resistant structural components. The three kinds of portion-wall specimen, cut from the mud wall considering the carrying mechanism, were applied to predict the hysteretic envelope of shear force-deformation curve and also the bracing unit multiplier of the original mud wall. The predictions for the four different types of mud wall specification were much similar in all cases to the corresponding experimental results of shear wall test, and the validity of the proposed method was thus confirmed.
\end{abstract}

Keywords : Japanese traditional structural system, Mud wall with uncovered posts and beams, Structural design, Portion-wall test, Hysteretic envelope curve, Multiplier of bracing unit 伝統構法 土壁真壁 構造設計 部分壁体試験 履歴包絡線 壁倍率

\section{1.はじめに}

最近の土壁に関する研究報告は、単なる実験報告的なものから抵 抗機構の解明やせん断力ー変形関係を推定する内容に移行しつつあ る。土壁のせん断性状を推定するための初期の研究では、鈴木ら"1 と三芳ら 23314 と中尾ら5 ${ }^{53}$ 荒壁のみの土壁、荒壁+中塗りの土壁の 比較実験結果から、それぞれの負担せん断力を求めている。しかし ながら、荒壁のみを塗った土壁では、壁厚が薄く、壁土がせん断破 壊しや寸いが、荒壁十中塗りとした土壁ではせん断破壊しないな ど、両者で破壊の挙動が異なる。そのため、比較実験などで得られ た荒壁と中塗りの負担せん断力は、必ずしも土壁内の挙動を反映し たものとは言い難い。

荒壁と中塗りを一体として扱って土壁の抵抗機構を解明した筆者 らの研究(けてねでは、土壁の破壊モードは、壁土のせん断破壊が先行 する場合と先行しない場合に分類できることが解明された。せん断 破壊が先行しない破壊モードでは、壁土がせん断破壊するときの耐 カよりも、土壁中で貫が回転することによる圧縮抵抗や、士壁のパ ネルが木造軸組内で回転することによる隅角部での対角方向の圧縮 抵抗によって、壁土が破壊するときの耐力の方が低く、こうした圧 縮抵抗が土壁の主要な抵抗機構であることが示された。それぞれの 破壊モードに対応する抵抗機構で構成された力学モデルを構築する
ことで、耐力壁の剛性や耐力を求めることができ、また、壁長が長 くなるとせん断破壊が先行することも理論的に示された。

その後、山田 ${ }^{91}$ 、中尾ら ${ }^{(0)}$ は、土壁に特有な貫近傍の壁土の耐荷 機構を、土の圧縮強度や摩擦などに置き換え、小舞入り壁土の圧縮 強度を用いて、鉄筋コンクリート構造で実用化されているひび割れ を考慮した数值解析手法を応用して、土壁の挙動を再現する試みを 報告している。田淵ら ${ }^{11}$ は、土壁内で回転する貫の抵抗を弾性床上 の梁理論を用いて、また軸組仕口のモーメント抵抗を精㣲に計算し て、軸組のせん断抵抗力を求め、30 c m 角の小舞入り土壁のせん断 試験結果から得られた土壁のせん断抵抗力と足し合わせることで、 耐力壁の包絡線を推定する手法を報告している。しかし、これらの 解析的な報告では、数值解析において土壁特有の耐荷機構をバネモ デルなどで表現する際に材料定数を得るための試験法が確立されて おらず、様々な仕様の土壁の材料定数を実験的に解明してモデル化 することが今後の課題である。

一方、文献》に示されているように、土壁の各抵抗要素である隅 角部の圧縮抵抗、壁土内での貫の回転による圧縮抵抗、及び、軸組 に差し込まれた間渡し竹のダボ的抵抗は、壁土の破壊によってお互 いに影響し合うため、こうした耐荷機構単体の挙動を評価するため の要素試験結果から耐力壁のせん断举動を推定することには、限界

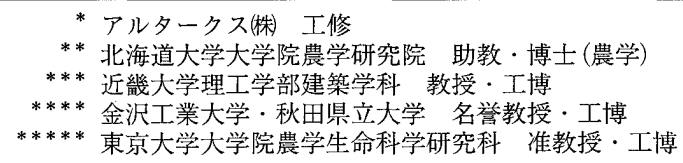

Alltags, Ltd., M. Eng.

Assistant Prof., Research Faculty of Agriculture, Hokkaido University, Dr. Agr.

Prof., Dept. of Architecture, Graduate School of Science \& Engineering, Kinki Univ., Dr. Eng. Prof., Emeritus, Kanazawa Institute of Technology and Akita Prefectural Univ., Dr. Eng. Assoc. Prof., The University of Tokyo, Graduate Shool of Agricultural and Life Sciences, Dr. Eng. 


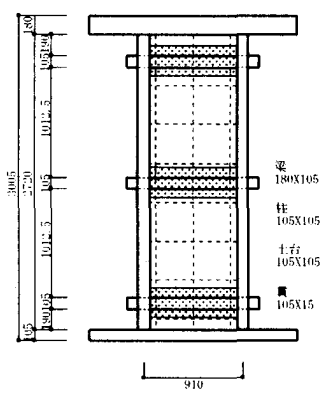

(a) K1P (京都仕様)

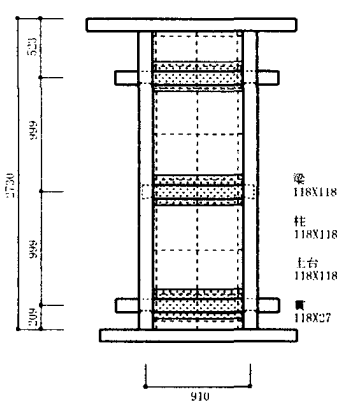

(c) S1P (滋賀仕様)

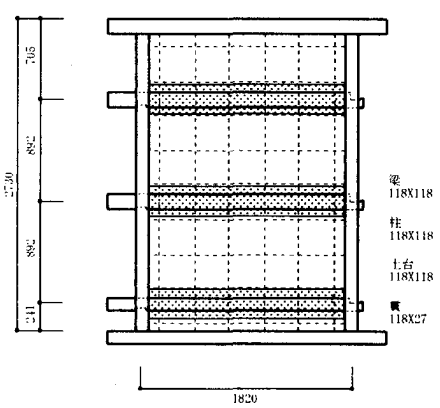

(e) A2P (秋田仕様)

図 1 試験体図

があることも報告されている。

そこで、本論文では、土壁のせん断性状を推定するための現実的 な要素試験法として、2 種類の部分壁体を用いる試験法を提案す る。そして、京都・滋賀・秋田の異なる 3 種類の仕様の土壁に対し て、壁長が $1 \mathrm{P}(910 \mathrm{~mm})$ と $2 \mathrm{P}(1820 \mathrm{~mm})$ の土壁の耐力試験結果から得 られたせん断力ー変形角の包絡線と壁倍率を、同時に製作された部 分壁体試験結果から推定し、その方法論の妥当性を検証する。

\section{2. 検証対象となる土壁の加力実験の概要}

\section{1 土壁の試験体}

本論文での検証用土壁試験体を図 1 に、試験体仕様一覧を表 1 に 示す。試験体は下地の構成と壁士が異なる京都仕様、滋賀仕様、秋 田仕様の 3 種類とし、耐力壁の壁長は $1 \mathrm{P}$ と $2 \mathrm{P} の 2$ 種類とした。 それぞれの仕様を以下に示す。

\section{（1）京都仕様の土壁 (試験体名:K1P, K2P)}

柱と土台は $105 \mathrm{~mm}$ 角で、梁は $105 \mathrm{~mm} \times 180 \mathrm{~mm}$ 、貫は $15 \mathrm{~mm} \times 105 \mathrm{~mm}$ の スギ材である。下地の小舞は幅 $18 \mathrm{~mm} \sim 21 \mathrm{~mm}$ 、厚さ $3 \mathrm{~mm}$ の割り竹と し、約 $50 \mathrm{~mm}$ 閒隔で配した。閒渡しは幅 $21 \mathrm{~mm} \sim 24 \mathrm{~mm}$ 、厚さ $3 \mathrm{~mm}$ の割
表 1 試験体仕様一覧

\begin{tabular}{|c|c|c|c|c|c|c|c|c|}
\hline \multirow{2}{*}{ 試験体名 } & \multicolumn{4}{|c|}{ 土 } & \multicolumn{2}{|r|}{ 小舞 } & \multicolumn{2}{|r|}{ 而渡L } \\
\hline & 産地 & 荒壁厚 & 中矣厚 & 壁厚 & 材料 & 断面 & 材料 & 断面 \\
\hline K1P & 京都 & $35 \sim 40$ & $10 \sim 15$ & 60 & 竹 & $3 \times 18 \sim 21$ & 竹 & $3 \times 21 \sim 24$ \\
\hline K2P & 京都 & $35 \sim 40$ & $10 \sim 15$ & 60 & 竹 & $3 \times 18 \sim 21$ & 竹 & $3 \times 21 \sim 24$ \\
\hline S1P & 滋賀 & $50 \sim 60$ & $15 \sim 20$ & 90 & 竹 & $3 \times 18 \sim 21$ & 竹 & $3 \times 21 \sim 24$ \\
\hline A1P & 秋田 & $50 \sim 60$ & $15 \sim 20$ & 90 & 木 & $9 \times 21$ & 木 & $9 \times 24$ \\
\hline A2P & 秋田 & $50 \sim 60$ & $15 \sim 20$ & 90 & 木 & $9 \times 21$ & 木 & $9 \times 24$ \\
\hline
\end{tabular}

\begin{tabular}{|c|c|c|c|c|c|c|c|}
\hline \multirow{2}{*}{ 試験体名 } & \multicolumn{2}{|c|}{ 土台 } & \multicolumn{2}{|c|}{ 梁 } & \multicolumn{3}{|c|}{ I } \\
\hline & 材料 & 断面 & 材料 & 断面 & 材料 & 断面 & 伏世 \\
\hline K1P & スギ & $105 \times 105$ & スギ & $105 \times 180$ & スギ & $15 \times 105$ & 寒冷紗 \\
\hline K2P & スギ & $105 \times 105$ & スギ & $105 \times 180$ & スギ & $15 \times 105$ & 寒冷紗 \\
\hline S1P & スギ & $118 \times 118$ & スギ & $118 \times 118$ & スギ & $27 \times 118$ & ヘチマ \\
\hline$\overline{A 1 P}$ & スギ & $118 \times 118$ & スギ & $118 \times 118$ & スギ & $27 \times 118$ & 橝蓝 \\
\hline A2P & スギ & $118 \times 118$ & スギ & $118 \times 118$ & スギ & $27 \times 118$ & 橉富 \\
\hline
\end{tabular}

り竹とし、約 $300 \mathrm{~mm}$ 間隔で配し、軸材に $10 \mathrm{~mm}$ 程度差し込んだ。京都 仕様の土壁は、壁厚は荒壁 $35 \sim 40 \mathrm{~mm}+$ 中塗り $10 \sim 15 \mathrm{~mm}$ ずつの計 $60 \mathrm{~mm}$ 、竹小舞下地からなる壁体に京都 (深草) 産の壁士を塗った壁長 が $1 \mathrm{P}$ と $2 \mathrm{P}$ の 2 種類の耐力壁としての試験体 (K1P と K 2P) である。 横貫はすべて通し貫で、全試験体で横貫に沿って寒泠紗による貫伏 せで補強した。壁長 $2 \mathrm{P}$ の試験体は 4 体 (K2P-1 〜 4) 女り、全て縦貫 が設けられている。K $2 \mathrm{P}-1 \sim 3$ は縦貫にも寒冷紗による貫伏せ補強 を施し、K $2 \mathrm{P}-4$ は縦貫に貫伏せ補強のない試験体とした。

\section{（2）滋賀仕様の土壁 (試験体名:S1P)}

軸組は $118 \mathrm{~mm}$ 角で、貫は $27 \mathrm{~mm} \times 118 \mathrm{~mm}$ のスギ材である。下地の小 舞は幅 $18 \mathrm{~mm} \sim 21 \mathrm{~mm}$ 、厚さ $3 \mathrm{~mm}$ の割り竹とし、約 $50 \mathrm{~mm}$ 間隔で配した。 間渡しは幅 $21 \mathrm{~mm} \sim 24 \mathrm{~mm}$ 、厚さ $3 \mathrm{~mm}$ の割り竹とし、約 $300 \mathrm{~mm}$ 間隔で配 し、軸材に $10 \mathrm{~m} \mathrm{~m}$ 程度差し込んだ。滋賀仕様の土壁は、壁厚は荒壁 $50 \sim 60 \mathrm{~mm}$ 十中塗り $15 \sim 20 \mathrm{~mm}$ ずつの計 $90 \mathrm{~mm}$ 、竹小舞下地からなる壁 体に滋賀産の壁土を塗った壁長が $1 \mathrm{P}$ の耐力壁としての試験体 （S1P）である。貫はすべて通し貫で、横貫に沿ってへチマによる貫 伏せで補強した。

\section{( 3 ) 秋田仕様の土壁 (試験体名: A1P, A2P)}

軸組は $118 \mathrm{~mm}$ 角で、貫は $27 \mathrm{~mm} \times 118 \mathrm{~mm}$ のスギ材である。下地の小 舞は幅 $21 \mathrm{~mm}$ 、厚さ $9 \mathrm{~mm}$ のスギ材とし、約 $60 \mathrm{~mm}$ 間隔で配した。間渡し は幅 $24 \mathrm{~mm}$ 、厚さ $9 \mathrm{~mm}$ のスギ材とし、約 $300 \mathrm{~mm}$ 間隔で配し、軸材に $10 \mathrm{~mm}$ 程度差し込んだ。秋田仕様の土壁では、壁厚は荒壁 $50 \sim 60 \mathrm{~mm}+$ 中 塗り $15 \sim 20 \mathrm{~mm}$ ずつの計 $90 \mathrm{~mm}$ 、竹の代わりにスギを用いた小舞下地 からなる壁体に秋田産の壁土を塗った壁長が $1 \mathrm{P}$ と $2 \mathrm{P} の 2$ 種類の 耐力壁としての試験体 (A1P と A 2P) である。柱と貫の仕口の一方は 通し貫、他方は下げ鎌で、共に楔で固定している。全試験体で横貫 に沿って稲蒠による貫伏せで補強した。

\section{2 . 2 載荷方法}

タイロッド式で加力実験を行い、見かけの変形角が、1/600・1/ $450 \cdot 1 / 300 \cdot 1 / 200 \cdot 1 / 150 \cdot 1 / 100 \cdot 1 / 75 \cdot 1 / 50 \cdot 1 / 30 \cdot 1 / 15(\mathrm{rad}$.$) の$ 各 3 回の正負交番繰り返し加力とし、その後、見かけの変形角 $1 / 10$ （rad. ) まで一方向単調加力を行った。

\section{3. 水平耐荷機構と土壁のカ学モデル6 8)}

3. 1 土壁の水平耐荷機構 


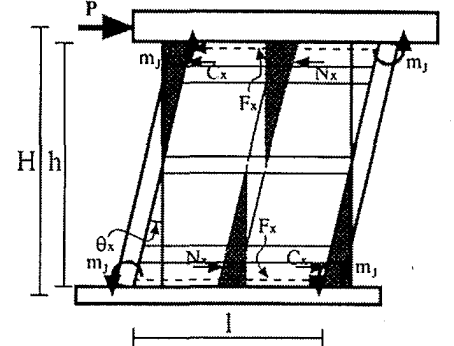

(a) $\mathrm{X}$ 方向

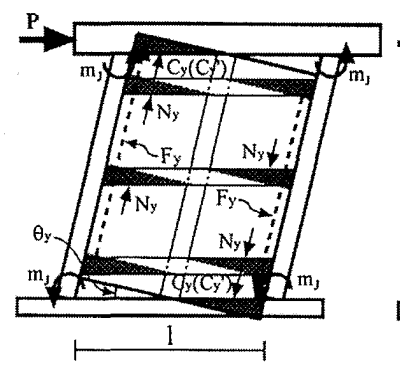

(b) Y方向

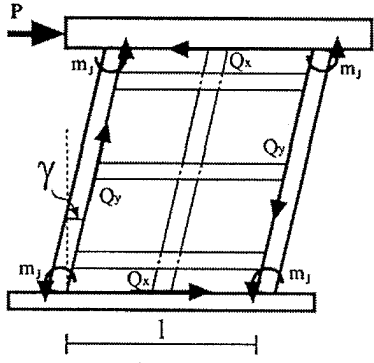

(c) せん断変形

(図は、左 $\rightarrow$ 右に加力した時の $\theta \mathrm{x} 、 \theta \mathrm{y} 、 \gamma$ 正の方向を示す。)

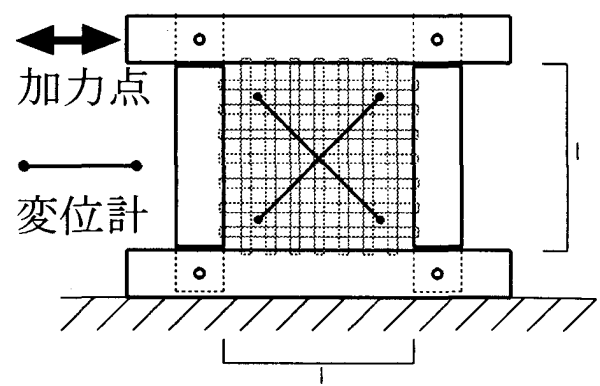

図 3 純せん断部分壁体試験体

図 2 土壁の耐荷機構モデルに基づく抵抗応力

耐力壁としての土壁は、作用する水平力による外力モーメントか ら土台・横架材と柱との仕口部の抵抗モーメント m, を仕口の個数 だけ累加した負担分 $\Sigma \mathrm{m}$, を除いた外力モーメントに対して、図 2 の (a) 〜 (c) の耐荷機構で抵抗する。

図 2 (a)、(b) の抵抗要素は、土壁のパネルが軸組内で 1 枚の剛版と して回転することにより抵抗するときの変形成分を、X方向と $\mathrm{Y}$ 方 向に分類したものであり、それぞれの変形成分の耐荷機構で抵抗す る。同図の耐荷機構には、以下の 4 つの抵抗要素が含まれる。

(1) 土壁のパネルが軸組内で回転することで、軸組一土壁間に生じ る圧縮力による抵抗要素C (図 2 中の $\mathrm{C}_{\mathrm{x}}$ 及びC ${ }_{\mathrm{y}}$ )

（2）貫が壁体内で土壁をこじるように回転することで、貫－壁土間 に生じる压縮力による抵抗要素 $\mathrm{N}\left(\right.$ 図 2 中の $\mathrm{N}_{\mathrm{x}}$ 及び $\mathrm{N}_{\mathrm{v}}$ )

(3) 軸組に差し込まれた間渡竹のダボ的抵抗のために、軸組一土壁 間に生じるせん断力による抵抗要素 $\mathrm{F}$ (図 2 中の $\mathrm{F}_{\mathrm{x}}$ 及び $\mathrm{F}_{\mathrm{y}}$ )

但し、抵抗要素Cについては、地貫や頭貫が土台や横架材の近く に挿入されていると、大変形時にこれらの貫のこじりによる破壊と 土壁隅角部の圧壊が熬がり、隅角部の圧縮抵抗は大幅に低下寸るの で、地貫や頭貫が無い場合と区別して、上下の貫がある場合をC で表記する。

抵抗要素 $\mathrm{F}$ に関しては、土壁が乾燥収縮により散り切れが生じて 扝り、軸組みと土壁の付着力は消失していると判断し、間渡竹の機 械的な抵抗のみを見かけの摩擦力として扱う。

なお、C、N、Fは上記 $(1) \sim(3)$ の各耐力要素の種類を示し、図 2 中でこれらに添え字の付いたものは、各耐力要素で土壁から軸組 に作用する力を、添え字の $\mathrm{x} ， \mathrm{y}$ は力の作用方向を表している。

図 2 (c) の抵抗要素は、土壁の全体又は局部にせん断ひび割れが 発生して、土壁自体がせん断変形することにより抵抗する。

\section{2 土壁の耐荷カ学モデル}

土壁の変形成分は、図 $2(\mathrm{a}) \sim(\mathrm{c})$ の $\mathrm{X}$ 方向の回転変形 $\theta \mathrm{x} 、 \mathrm{Y}$ 方 向の回転変形 $\theta \mathrm{y}$ 、せん断変形 $\gamma$ に分解でき、各変形により発生す る抵抗モーメント $M_{\theta x} 、 M_{\theta y} 、 M_{\gamma}$ は、式(1)のように、仕口の抵抗 による軸組負担分 $\Sigma \mathrm{m}$ ，を除いた外力モーメントとそれぞれの值は 釣り合う。

$$
P H-\sum m_{J}=M_{\theta x}=M_{\theta y}=M_{\gamma}
$$

また、土壁では図 2 (a) 〜 ( c ) の挙動が同時に発生しており、各変 形による変形角の総和は、式 $(2)$ のように、土壁の真の変形角 $\mathrm{R}$ と 等しくなる。

$$
R=\theta x+\theta y+\gamma
$$

最大耐力は、文献 ${ }^{8)}$ で検証したように、土壁がせん断破壊しない 場合は、X方向の回転変形またはY方向の回転変形による破壊で決 まり、せん断破壊する場合は、せん断変形による破壊で決まる。式 （1）と（2）より、(a)〜 ( c ) の変形成分は直列バネ配置的な関係にある ことがわかる。このことより、各変形成分に対する $M_{\theta \times} 、 M_{\theta y} 、 M$ のうちいずれかが最初に最大值に達した時に、士壁は最大耐力を 迎え、その後の変形性状は、最初に最大に達した変形成分による抵 抗モーメントのみが耐力低下することにより、その変形成分のみの 破壊が進行して終局状態に至る。

従って、土壁の各変形成分の $\mathrm{M}_{\theta \mathrm{x}}-\theta \mathrm{x}$ 関係、 $\mathrm{M}_{\theta \mathrm{y}}-\theta \mathrm{y}$ 関係、 $\mathrm{M}_{\gamma}-\gamma$ 関係が直列バネ配置となる関係を利用して、土壁のせん断 カー 変形角関係を推定できることがわかる。

\section{4.土壁の耐荷挙動を推定するための部分壁体試験体の提案}

4. 1 土壁のせん断カ一せん断変形角関係を推定する部分壁体試

\section{験体の提案}

土壁のせん断力ー せん断変形角関係を推定するための『部分壁体 試験体』を図 3 に示す。この試験体は、せん断力を土壁の各辺から 均等に作用させるために、全ての小舞竹を軸材に差し込んで石高で 固定した。また、せん断力を土壁のみに作用させるために、軸材を ピン接合とした。せん断応力度は、実験で得られたせん断力を土壁 の断面積で除して算出し、せん断変形角 $\gamma$ は、土壁に埋め込まれた 標点で直接計測された対角方向伸縮量から算出した。なお、繸貫に 沿った貫伏せ補強は、土壁のせん断補強に有効であるため、縌貫に 沿って貫伏せ補強を施した試験体 (K2P1〜3) に対応する部分壁体試 験体では、全面に貫伏せを貼った状態で実験した。

\section{4. $2 \theta$ y が優勢な土壁のせん断カー変形角関係を推定する部分 壁体試験体の提案}

（1）の京都仕様の $1 \mathrm{P}$ 試験体の実験結果から得られた $\theta \mathrm{x} 、 \theta \mathrm{y}$ 、 $\gamma$ の変形角の推移を図 4 に示す。せん断変形 $\gamma$ は土の表面で計測し ていたため精度はあまり良くなく、 $\theta \mathrm{x}+\theta \mathrm{y}+\gamma$ が 1.0 を多少超え ているが、 $1 \mathrm{P}$ 試験体では $1 / 10 \mathrm{rad}$.まで $\theta$ y / Rが概ね 1.0 となっ た。この土壁はせん断耐力が高く、壁長が短いので、せん断変形角 $\gamma$ はほとんど発生しないため、 $\theta \mathrm{y}$ が真の変形角 Rの大部分を占 め、土壁の短辺側に破壊が集中して、 $M_{\theta v}$ により最大耐力が決ま

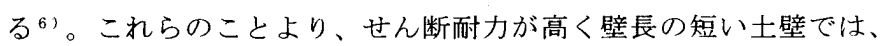




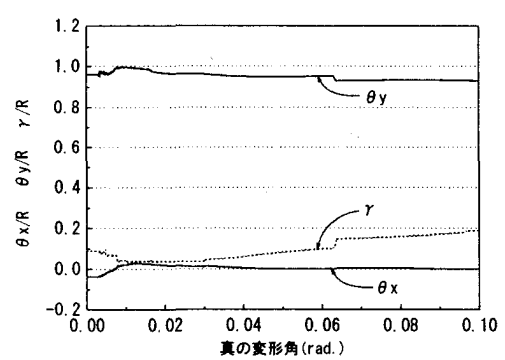

図 4 K 1 P における変形角の推移

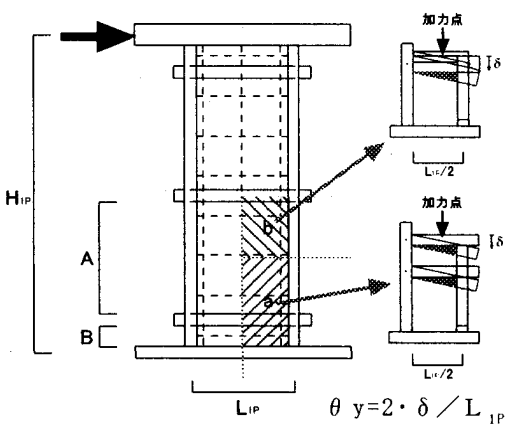

図 5 部分壁体試験体と壁体部位の関倸

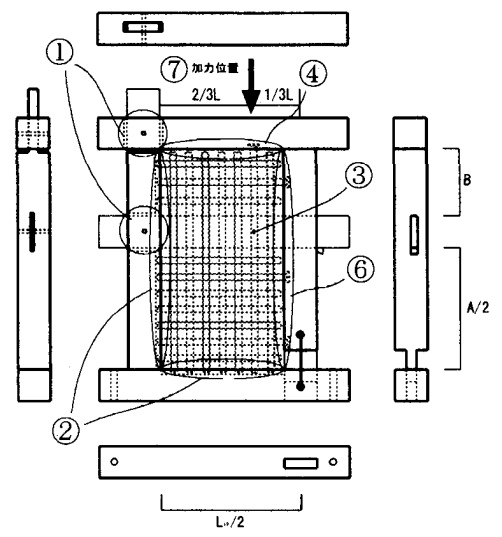

（a）隅角部圧縮部分壁体試験体

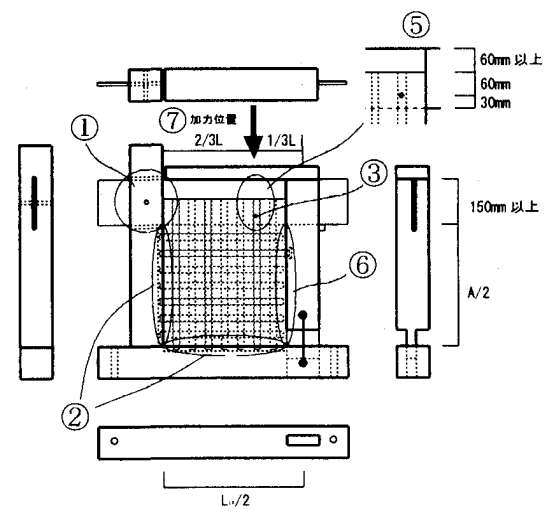

(b) 貫のこじり部分壁体試験体

図 6 部分壁体試験体の仕様図

表 2 部分壁体試験体の製作と加力方法上の注意事項

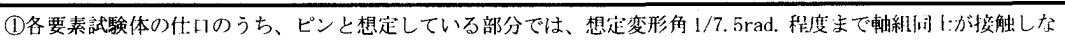
いように峦問を確保する。

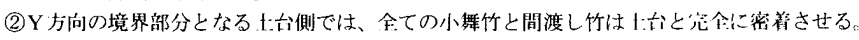

(3)実際の的力壁と京じように、閒渡し竹住貫に釷打ちする。

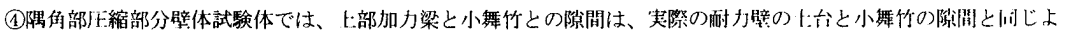
うに空ける。

(5)貫のこじり部分譬体試験体では、壁士の上端と加力部との間は、想定変形觕 $1 / 7.5 \mathrm{rad}$, 程度まで接触しないよう に腺問を確保する。

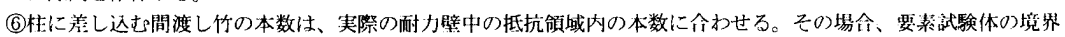
が間渡し竹の多术的作用比影響しない上うにするため江、最下端に配置される闑渡し竹は、位置を変更する。

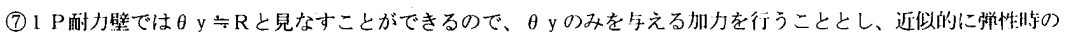

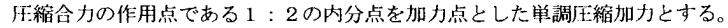

$\mathrm{M}_{\theta \mathrm{y}}-\theta \mathrm{y}$ 関係のみを推定すれば、せん断力ー 変形角関係をほぼ推 定できることがわかった。

文献》では $1 \mathrm{P}$ 耐力壁のY方向の変形成分による抵抗要素の発現 機構を確認するために、隅角部での圧縮抵抗 C、土壁内での貫の回 転によるこじり抵抗 $\mathrm{N}$ 、軸組－土壁間の間渡し竹のダボ的作用によ るせん断抵抗 Fが、それぞれ単独に生起する様に工夫した『要素試 験体』を製作し、実験を行った。隅角部での圧縮抵抗 C と軸組 - 土 壁間の間渡し竹のダボ的作用によるせん断抵抗 F は、土壁内での貫

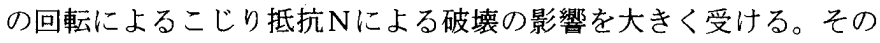
ため、文献 ${ }^{6}$ の抵抗要素の一部を除去した試験体群による一連の比 較実験から抽出された実際の土壁内における隅角部、貫、間渡し竹 に起因する举動は、それぞれを単独に抵抗する様に工夫した要素試 験結果とは異なった。

そこで、 $\mathrm{M}_{\theta \mathrm{y}}-\theta \mathrm{y}$ 関係のみを推定するために、隅角部、貫、間 渡し竹に関わる抵抗要素の相互作用を含めて、それぞれの抵抗要素 の挙動を再現できるように、1 $\mathrm{P}$ 耐力壁の隅角部分と中央貫部分の 耐荷機構の挙動を、図 5 のように仮定して切り出した『部分壁体試 験体』を考案した。それらは、隅角部での圧縮力による抵抗を評価 するための『隅角部圧縮部分壁体試験体』と、中央貫の土壁内での 回転に対する抵抗力を評価するための『貫のこじり部分壁体試験 体』の 2 体で構成されている。図6(a)、(b)に各部分壁体試験体の試 験体図を、表 2 にその製作要領を示す。

各部分壁体の試験結果から耐力壁内の抵抗要素の数を考慮して、 $\theta \mathrm{y}$ が真の変形角 Rの大部分を占める $1 \mathrm{P}$ 耐力壁のせん断力一変形 角関係を推算する方法について以下に示す。

各部分壁体試験体の変位 $\delta$ (図 5 中に示す) と $1 \mathrm{P}$ 耐力壁の真の変 形角 R は、壁土のせん断変形を無視すると、 $\mathrm{R} \div \theta_{\mathrm{y}}=2 \delta / \mathrm{L}_{\text {। }}$ $\left(\mathrm{L}_{\mathrm{IP}}\right.$ は壁長 $\left.=910 \mathrm{~mm}\right)$ で関倸づけられる。この $2 つ の$ 部分壁体試験体
の予め設定する所定変形角時の荷重から、1 P 耐力壁の水平せん断 カ $\mathrm{P}_{1 \mathrm{P}}$ は式 (3) で推算できる。

$P_{1 P}=\left(N_{c} \times P_{\sigma F} \times L_{1 P} / 3+N_{n} \times P_{N F} \times L_{P} / 3\right) / H_{1 P}$

$\mathrm{P}_{C F}$ : 隅角部圧縮部分壁体試験体の所定変形時荷重

$\mathrm{P}_{\mathrm{NF}}:$ 貫のこじり部分壁体試験体の所定変形時荷重

$\mathrm{L}_{1 \mathrm{P}}: 1 \mathrm{P}$ 耐力壁の壁長

$\mathrm{H}_{1 \mathrm{P}}$ : $1 \mathrm{P}$ 耐力壁の高さ

$\mathrm{N}_{c}$ : 隅角部圧縮抵抗を受ける抵抗要素の個数 $(=2)$

$\mathrm{N}_{\mathrm{n}}$ : 貫のこじり抵抗を受ける抵抗要素の個数

$(=2 \times($ 貫の段数 -2$))$

ここに、 $\mathrm{L}_{\mathrm{iP}} / 3=2 / 3\left(\mathrm{~L}_{\mathrm{PP}} / 2\right)$ であるので部分壁体試験体の中立軸か ら加力位置までの距離を意味する。

\section{3 部分壁体試験体の試験方法と破壊状況}

部分壁体試験は図 6 の加力位置を単調圧縮加力し、変形角 $\theta$ y $は$ 変位 $\delta$ から算出した。部分壁体試験体の代表的な破壊状況と $1 \mathrm{P}$ 試 験体の隅角部分の破壊状況を写真 1 に示寸。隅角部圧縮部分壁体試 験体では、隅角部で壁土が圧壊して小舞竹が座屈した場合( 写真 1 （b）と貫付近の壁土が圧壊して小舞竹が隅角部から離れた位置で座 屈した場合 (写真 1 (c)) が見られたが、前者の破壊状況が $1 \mathrm{P}$ 耐力壁 における隅角部の破壊状況 (写真 1 (a)) をよく表している。貫のこじ り部分壁体試験体では、写真 1 (d) のように、貫が荒壁のみを圧縮 破壊し、表面の中塗りには破壊が生じず、中叙りが厚み方向へ多少 膨らむ破壊となり、1 $\mathrm{P}$ 耐力壁の中央貫付近の破壊状況とほぼ同じ 破壊状況であった。

\section{4４部分壁体試験体による耐力壁のせん断性状の推算}




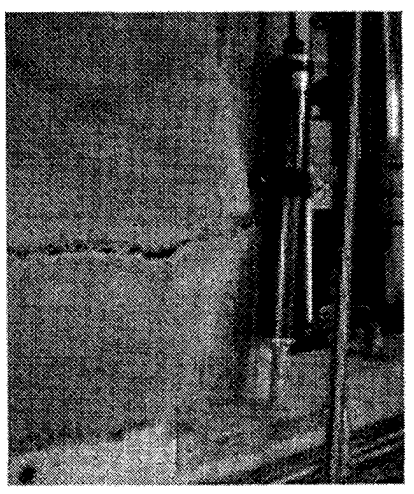

（a） $1 \mathrm{P}$ 試験体の隅角部

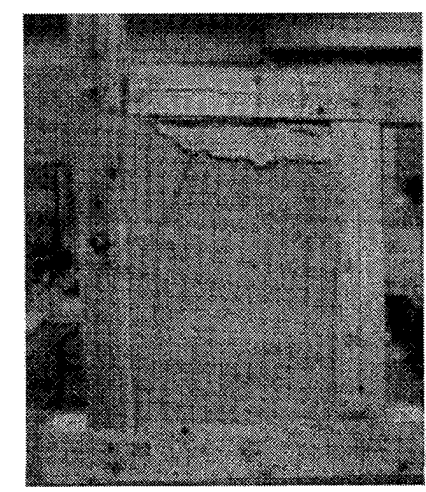

（b）隅角部圧縮部分壁体試験体
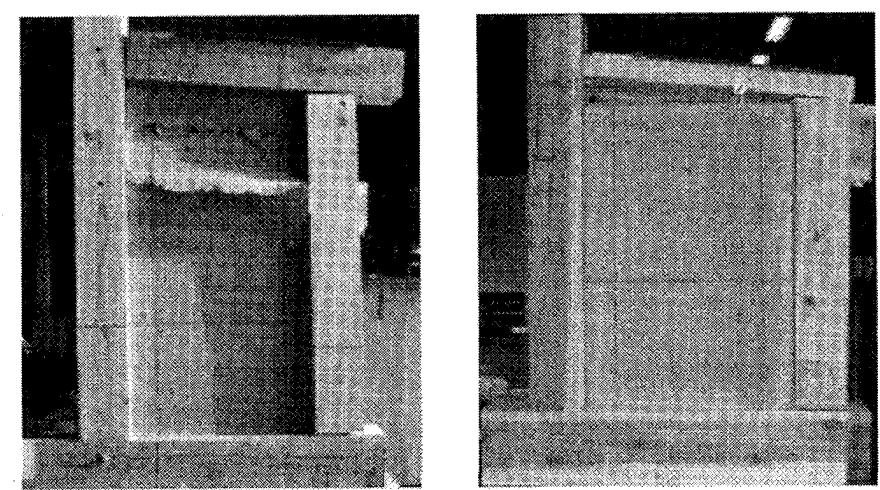

（c）隅角部圧縮部分壁体試験体

（d）貫のこじり部分壁体試験体

写真1 $1 \mathrm{P}$ 及び部分壁体の試験体と破壊状況

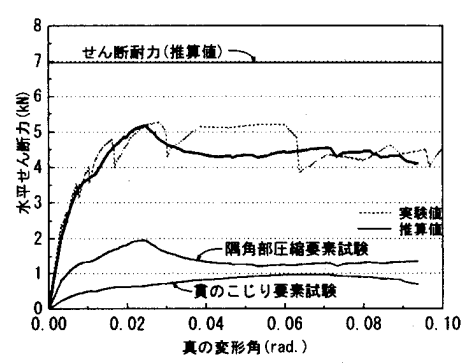

(a) K1P (京都仕様)

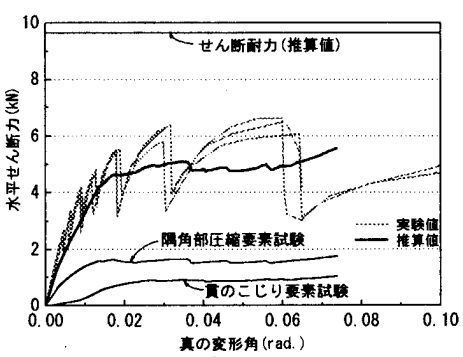

(b) S1P（滋賀仕様）

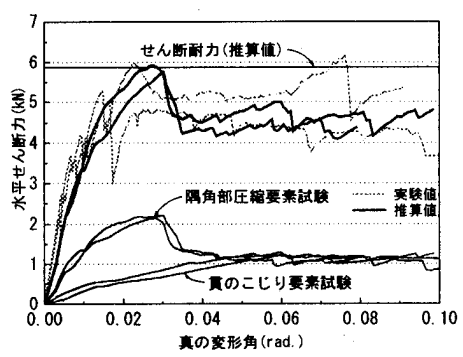

(c) A1P (秋田仕様)

図 $71 \mathrm{P}$ 耐力壁のせん断力ー変形角関係の検証結果

2 章で説明した京都仕様、滋賀仕様、秋田仕様の $1 \mathrm{P}$ 耐力壁に対 忘する部分壁体試験体をそれぞれ製作した。その加力試験から得ら れた部分壁体試験体の荷重 - 変形角関係と式 (3) を用いて、1 P 耐 力壁のせん断力ー 変形角関係を推算した。部分壁体試験結果に基づ く推算值と $1 \mathrm{P}$ 耐力壁の実験結果との比較を図 7 に示す。

土壁の仕様にかかわらず、部分壁体試験結果から得られたせん断 カ一変形角関係の推算値は、最大耐力付近まで赛験值と概ね一致し た。K1P、S1Pに関しては、純せん断部分壁体試験結果から文献 ${ }^{8)}$ 検証した式 (8)（5，2節で後述)により推算した最大せん断耐力 (同 図中に横の太線で示す）が最大耐力を上回っているので、せん断破 壊が先行しなかったことが裹付けられた。一方 A 1 P の推算值に関し ては、せん断破壊が生じない場合の最大耐力とせん断耐力はほぼ等 しい結果となった。耐力壁の実験では、隅角部の圧壊や土壁内での 貫の回転による破壊が、壁土のせん断破壊と同時進行で拡大しなが ら最大耐力に達していた。よって、部分壁体試験に基づく推算結果 は、土壁の最大耐力のみではなく破壊性状も含めて捉えていること がわかる。

また、写真1 (c) のような破壊が見られた試験体(図 7 の K1P と A1P) では、耐力壁の実験結果に対して推算值が最大耐力まではほぼ一致 しているが、最大耐力以降の急激な耐力低下が見られる。一方、写 真1（b）のような破壊が見られた試験体（図７のS1P) では、耐力壁の 実験結果より推算値の耐力はやや低めであるが、最大耐力以降の急 激な耐力低下は見られず、1 P 耐力壁の実験結果と近い性状を示し た。

隅角部圧縮部分壁体試験でこのように破壊状況が異なるのは、繰 り返し加力の履歴の有無が原因と考えられる。すなわち、耐力壁の 実験では、正負漸増繰り返し加力により、当該の隅角部を含んだ対 角方向が伸びる方向となる加力によって、貫と横架材間の土壁は最
表 $31 \mathrm{P}$ 耐力壁の壁倍率の実験值と推算値の比較

\begin{tabular}{|c|c|c|c|c|c|c|c|c|c|c|}
\hline & \multicolumn{2}{|c|}{ 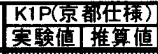 } & \multicolumn{4}{|c|}{ 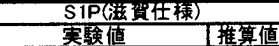 } & \multicolumn{4}{|c|}{787} \\
\hline $\mathrm{Py}$ & 29 & 28. & 3.7 & 4.1 & 4.2 & 3.9 & 3.6 & 32 & 3.8 & 3.1 \\
\hline $\mathrm{Pu} \cdot(\sqrt{2 \mu-1})$ & 4.5 & 4.0 & 3.5 & 3.4 & 4.8 & 2.9 & 4.5 & 4.1 & 3.6 & 3.2 \\
\hline 2/3Pmax & 3.5 & 3.4 & 4.1 & 4.4 & 4.4 & 3.7 & 4.1 & 3.4 & 4.0 & 3.8 \\
\hline$P_{150}$ & 3.5 & 3.2 & 31. & 28 & 30 & 2.4. & 3.7 & 3.4 & 24 & 26 \\
\hline 壁倍率 & 1.6 & 1.6 & 1.7 & 1.6 & 1.7 & 1.4 & 2.0 & 1.8 & 1.4 & 1.5 \\
\hline
\end{tabular}

大耐力に至る前に、土壁内部での貫の回転により、既に小舞を境に 表と裏に剥離しており、その部分の壁土による小舞竹の座屈に対す る補剛効果は低下している。そのため、写真 1 (a) に見られるよう に、小舞の座屈は横架材の内法面から貫付近まで生じており、座屈 長さは横架材の内法面から貫付近までと長くなった。一方、写真 1 （c）のような破壊となった隅角部圧縮部分壁体試験体では、単調加 力であるため、最大耐力付近であっても貫と横架材閒の土壁には剥 離は生じず、小舞は壁士の表と裹の一体性の無い貫付近のみで座屈 しており、座屈長さは短かった。従って、隅角部圧縮部分壁体試験 体が、写真 1 (c) のような破壊となる場合の耐力は、(b)のような破壊 となる場合と比べて高くなる傾向が見られ、その後の耐力低下に関 しても耐力壁の挙動と異ったのであろう。

しかしながら、部分壁体試験の結果に基づく推算值は、耐力壁試 験結果を概ね再現できていると判断しうる。

\section{5 壁倍率の比較}

前節で求めた各試験体のせん断力ー変形角関係の推算結果から壁 倍率を評価し、表 3 でその推算值を耐力壁の実験結果から求めた実 験值と比較をして示した。K $1 \mathrm{P}$ では、推算値と実験值の壁倍率がほ ぼ同じ值となった。S1P と A 1 P では、初期剛性が実験値よりも推算 值の方が低い值となったため、壁倍率の決定因子 $\mathrm{P}_{150}$ が小さくなり、 


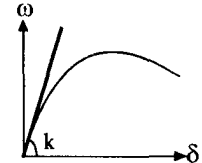

(a) $\omega-\delta$ 関係

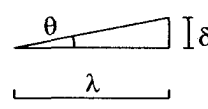

(b) 変位分布
図 8 死縮抵抗形式の想定

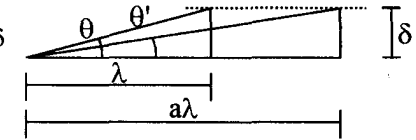

図 9 積分長さ $\lambda$ と回転角 $\theta$ 、 $\theta$, の関係
壁倍率も低い値となった。

\section{5. 部分壁体試験に基づく任意壁長䩂力壁のせん断カー变形角関係 の推定方法}

3. 2 節より、土壁の $\mathrm{M}_{\theta \mathrm{x}}-\theta \mathrm{x}$ 関係、 $\mathrm{M}_{\theta \mathrm{v}}-\theta \mathrm{y}$ 関係、及びM - $\gamma$ 関倸が分かれば、土壁のせん断カー変形角関係を推定できる ことがわかる。そこで、 4 章で提案した部分壁体試験体から、任意 壁長耐力壁の $\mathrm{M}_{\theta \mathrm{x}}-\theta \mathrm{x}$ 関係、 $\mathrm{M}_{\theta \mathrm{y}}-\theta \mathrm{y}$ 関係、及び $\mathrm{M}_{\gamma}-\gamma$ 関係 を推定し、任意壁長耐力壁のせん断力一変形角関係の推定方法を提 案する。

\section{5. $1 M_{\theta \times}-\theta \times$ 関係及び $M_{\theta y}-\theta$ y 関係の推算方法}

図 6 (a)、(b) の部分壁体試験体の実験結果から得られた抵抗モ一メ ントと回転角の関係から、軸組仕口が負担する耐力を差し引き、ま ず、部分壁体試験体の想定壁体 ( $1 \mathrm{P}$ 耐力壁) の短辺方向の $\mathrm{M}_{\theta}-\theta$ 関係を推算する。次に、推算した $\mathrm{M}_{\theta}-\theta$ 関係より、任意壁長耐力 壁の $\mathrm{M}_{\theta \mathrm{x}}-\theta \mathrm{x}$ 関係と $\mathrm{M}_{\theta \mathrm{y}}-\theta \mathrm{y}$ 関係を、積分長さの違いによるモー メントの変換により推算する。部分壁体試験体では、「積分長さ $\lambda 」$ が $0.5 \mathrm{P}$ の場合に相当するが、他の壁長、即ち任意の積分長さ $\lambda$ の 関倸に变換する方法を以下に示す。

文献泒によれ゙、土壁内では、抵抗要素 $\mathrm{F}$ の負担率は全体の 1 割 程度であるため、近似的には抵抗要素 $\mathrm{C}$ と Nが支配的と考えること ができる。部分壁体試験結果からはFの挙動を単独では抽出できな い。そこで、Fによる応力分布の影響は無視して、以下のように、 部分壁体試験体の実験結果から得られた $\mathrm{M}_{\theta}-\theta$ 関係を、求めたい 任意壁長耐力壁の $\mathrm{M}_{\theta \mathrm{x}}-\theta \mathrm{x}$ 関係と $\mathrm{M}_{\theta \mathrm{y}}-\theta \mathrm{y}$ 関係に補正する。図 8 (a)のような単位長さ当たりの圧縮応力 $\omega$ 一圧縮変位 $\delta$ 関係となる 压縮応力が、積分長さ $\lambda$ で図 8 (b) のように連続的に分布し、最外 端の圧縮変位が $\delta=\lambda \theta$ になる時の抵抗モーメント $\mathrm{M}_{\lambda}(\delta)$ を求め ると、式(4)になる。

$$
\mathrm{M}_{\lambda}(\delta)=\int_{0}^{\lambda} \mathrm{x} \cdot \omega(\mathrm{x} \cdot \theta) \mathrm{dx}
$$

一方、積分長さが a $\lambda$ で、最外端の圧縮変位が $\delta=\mathrm{a} \lambda \theta^{\prime}$ のと きの抵抗モーメントMa $\lambda(\delta)$ は式(5)になる。

$$
\mathrm{M}_{\mathrm{a} \lambda}(\delta)=\mathrm{a}^{2} \int_{0}^{\lambda} \mathrm{x} \cdot \omega\left(\mathrm{x} \cdot \theta^{\prime}\right) \mathrm{dx}
$$

最外端の压縮変位 $\delta$ が上記の両者で同じ値となる時、回転角 $\theta$ 及 び $\theta$ 'は図 9 のような関係にある。従って、最外端の圧縮変位 $\delta$ が 等しい場合、積分長さが a $\lambda$ の抵抗モーメントMa $\lambda(\delta)$ は同長さ が $\lambda$ のモーメント值 $\mathrm{M}_{\lambda}(\delta)$ a 倍で、そのときの回転角は 1 / a 倍 となる。

したがって、任意壁長耐力壁の $\mathrm{M}_{\theta \mathrm{x}}-\theta \mathrm{x}$ 関係と $\mathrm{M}_{\theta \mathrm{y}}-\theta \mathrm{y}$ 関係 は、それぞれ式(6)と式 (7) より推算できる。

$$
\begin{array}{ll}
\mathrm{M}_{\theta \mathrm{x}}=(\mathrm{h} / \mathrm{a})^{2} \cdot \mathrm{M}_{\theta} & \theta \mathrm{x}=(\mathrm{a} / \mathrm{h}) \cdot \theta \\
\mathrm{M}_{\theta \mathrm{y}}=(\mathrm{l} / \mathrm{a})^{2} \cdot \mathrm{M}_{\theta} & \theta \mathrm{y}=(\mathrm{a} / \mathrm{l}) \cdot \theta
\end{array}
$$

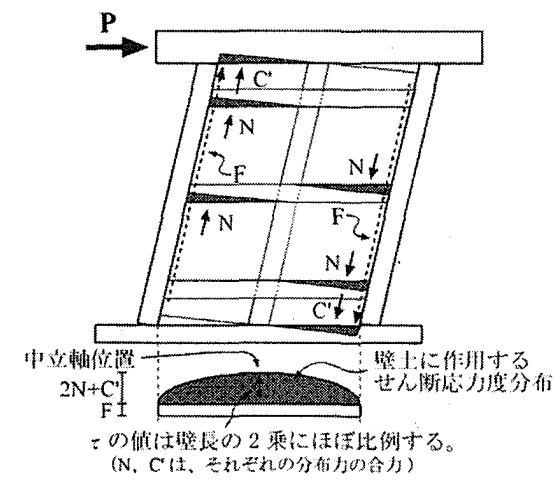

図 10 土壁断面内のせん断応力度の分布

ここに、

$M_{\theta}$ : 想定する耐力壁の短辺方向に相当する部分壁体試験体の抵抗 モーメント

$\theta$ ：想定する耐力壁の短辺方向に相当する部分壁体試験体の回転角

h ：推定する任意壁長の耐力壁の長辺方向の長さ

1 ：推定する任意壁長の耐力壁の短辺方向の長さ

a：想定する耐力壁の短辺方向に相当する部分壁体試験体の長さ

\section{5. $2 M r-\gamma$ 関係の推算方法}

図 10 に示すように、土壁内のせん断応力度の分布が $\mathrm{F}$ の忘力分 布の影響を受けるため、平均せん断応力度に対する最大せん断応力 度の比率が 1.45 倍となること ${ }^{8)}$ を考慮すると、任意壁長耐力壁のM $\gamma-\gamma$ 関係は、部分壁体試験から得られた $M_{\theta}-\gamma$ 関係から、式 (8) を用いて推算できる。

$$
\mathrm{M}_{\gamma}=\frac{\left(\mathrm{h} \cdot \mathrm{l} / \mathrm{b}^{2}\right) \cdot \mathrm{M}_{\mathrm{Q}}}{1.45}
$$

ここに、

$\mathrm{M}_{\mathrm{Q}}$ : 純せん断部分壁体試験体の抵抗モーメント

$\gamma$ : 純せん断部分壁体試験体のせん断変形角

$\mathrm{h}$ ：推定する任意壁長の耐力壁の長辺方向の長さ

1 ：推定する任意壁長の耐力壁の短辺方向の長さ

$\mathrm{b} ：$ 純せん断部分壁体試験体の一辺の長さ

\section{3 任意壁長耐力壁のせん断カ一変形角関係の推定方法}

$\mathrm{M}_{\gamma}$ で最大耐力が決まる場合を例に、図 11 に任意壁長耐力壁のせ 几断力一変形角関倸の推定方法を示す。

(1)部分壁体試験結果から、前述した方法により任意壁長耐力壁のM $\theta \times-\theta x$ 関係、 $\mathrm{M}_{\theta \mathrm{y}}-\theta$ y 関係、 $\mathrm{M}_{y}-\gamma$ 関係をそれぞれ推算する。 (2)各変形成分が直列バネの位置関係にあることを考慮して、最大耐 力までは、同一モーメントに対する各変形成分の変形角から式 (2) で $\mathrm{R}$ を求め、任意壁長の耐力壁の $\mathrm{M}-\mathrm{R}$ 関係を推算する。

(3)各変形成分により生じる $M_{\theta \times} 、 M_{\theta N} 、 M_{\gamma}$ のうちの何れかが最初 に最大耐力に達した時に、耐力壁全体の最大耐力 $\mathrm{M}_{\text {叫 }}$ を迎えると する。

(4)最大耐力以降の $M-R$ 関係は、最初に最大耐力に達した（破壊し

た）変形成分の最大耐力以降の $\mathrm{M}-\theta$ 関係または $\mathrm{M}-\gamma$ 関係を用い る。(各変形成分の破壊は独立でないため、破壊しなかった変形成分 


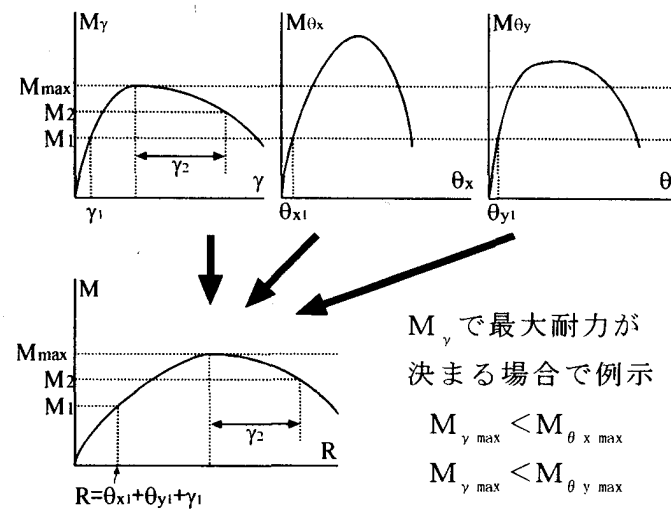

図 11 任意壁長耐力壁のせん断力一変形角関係 の推算方法

は弾性除荷しないが、ここでは、破壊しなかった変形成分は、最大 耐力を迎えた時の変形を保持すると仮定した。)

(5)推算した任意壁長耐力壁の $\mathrm{M}-\mathrm{R}$ 関係に、変形角 $\mathrm{R}$ 時の仕口の抵 抗による木造軸組の負担分 $\Sigma \mathrm{m}$,を加えて、任意壁長耐力壁のせん 断力ー変形角関係を推算する。

\section{6. 部分壁体試験に基づく任意壁長耐力壁のせん断カー变形角関 係推定方法の検証}

5 章で提案した手法を用いて、京都仕様の $\mathrm{K} 2 \mathrm{P}$ 、秋田仕様の A $2 \mathrm{P}$ のせん断力ー変形角関係及び壁倍率を推算し、耐力壁試験体の実験 結果と比較して、本評価法の妥当性を検証する。なお、京都仕様と 秋田仕様の軸組の耐力は、軸組のみの実験結果を使用した。

\section{12 P 耐カ壁のせん断カー変形角関係での検証}

$\mathrm{M}_{\theta \mathrm{x}}-\theta \mathrm{x}$ 関係と $\mathrm{M}_{\theta \mathrm{y}}-\theta \mathrm{y}$ 関係では、抵抗要素の構成が異なる。 部分壁体試験はY方向の挙動の再現を目的としているため、X方向 の挙動を直接求めることはできない。そこで、X方向では、剛性と 最大耐力が高いため、その挙動は弾性域付近にとどまり、塑性域に 入らないこと、及び、弾性域付近の挙動は、隅角部の圧縮抵抗が支 配的であることを考慮して、 $\mathrm{M}_{\theta \times}-\theta \mathrm{x}$ 関倸は、隅角部部分壁体試 験のみから推算した $1 \mathrm{P}$ 耐力壁の $\mathrm{M}_{\theta}-\theta$ 関係に、辺長比による補 正を行なうことにより推定した。

上述の方法を採り入れて、5 章の方法で求めた京都仕様と秋田仕 様の $2 \mathrm{P}$ 耐力壁のせん断力一変形角関係の推算值を、2 $\mathrm{P}$ 耐力壁試 験体の実験值との比較して、図 12 に示す。

縦貫に貫伏せ補強を施した $\mathrm{K} 2 \mathrm{P}-1 \sim 3$ の推算値の最大耐力は $\mathrm{M}_{y}$ で決まり、せん断破壊する形式となった。 $\mathrm{K} 2 \mathrm{P}-2$ を除き、最大耐力 以降も推算値と実験値はきわめてよく一致した。K $2 \mathrm{P}-2$ に関しては、 他の実験值よりも高く、土壁が高いせん断強度を示したので、せん 断破壊しない場合の関係を、 $\mathrm{M}_{\theta \mathrm{x}}-\theta \mathrm{x}$ 関係と $\mathrm{M}_{\theta \mathrm{y}}-\theta \mathrm{y}$ 関係から 推算をした。その結果(図 12 (b) ) は、 $M_{0}$ 、で最大耐力が決まり、最 大耐力以降もよく一致した。また、土壁が高いせん断強度を示した ので、せん断破壊が先行しなかったと推定される。

縦貫に貫伏せ補強のない $2 \mathrm{P}-4$ では、 $\mathrm{M}_{\gamma}$ で最大耐力が決まり、せ 儿断で破壊する形式となり、最大耐力以降も推算值と実験值はきわ めてよく一致した。秋田仕様の A 2 P では、 M 、゙最大耐力が決まり、 せん断で破壊する形式となり、純せん断部分壁体試験で計測值が行

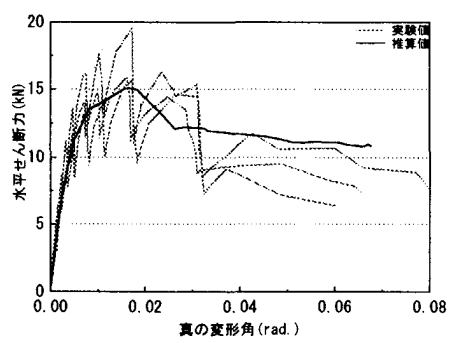

(a) $\mathrm{K} 2 \mathrm{P}-1 \sim 3$ (京都仕様)

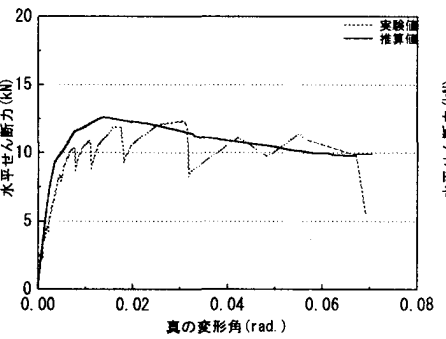

(c) $\mathrm{K} 2 \mathrm{P}-4$ (京都仕梯)

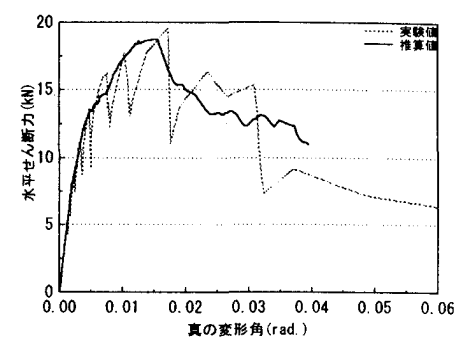

(b) K2P-2 (京都仕様)

(せん断変形なし)

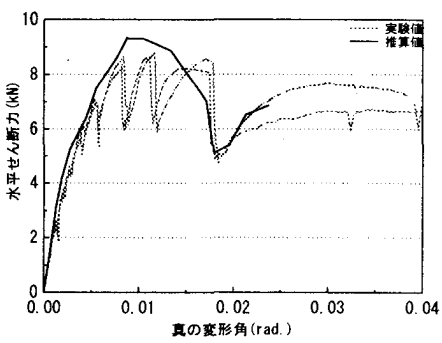

(d) A2P (秋田仕様)
図 $122 \mathrm{P}$ 耐力壁のせん断力一変形角関係の検証結果

表 4 2P 耐力壁の壁倍率での検証結果

\begin{tabular}{|c|c|c|c|c|c|c|c|c|c|c|}
\hline & \multicolumn{2}{|c|}{ 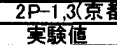 } & 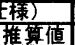 & \multicolumn{2}{|c|}{ 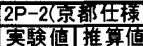 } & \multicolumn{2}{|c|}{ 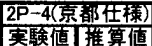 } & \multicolumn{3}{|c|}{ A2P(秋田仼溙) } \\
\hline Py & 11.2 & 10.1 & 87 & 11.7 & 10.9 & 9.1 & 8.2. & 53 & 5.2 & 4.6 \\
\hline $\mathrm{Pu} \cdot(\sqrt{2 \mu-1})$ & $7 \%$ & 8.0. & 9.5 & 87 & 9.8. & 9.3 & 10.4 & 5.9 & 39 & 41. \\
\hline 2/3Pmax & 10.6 & 10.5 & 10.0 & 13.0 & 12.7 & 83. & 8.5 & 5.9 & 5.8 & 6.2 \\
\hline$P_{150}$ & 12.6 & 13.9 & 12.9 & 15.7 & 14.9 & 10.1 & 11.2 & 7.5 & 7.4 & 8.3 \\
\hline 壁倍率 & 2.2 & 2.5 & 2.4 & 2.7 & 2.5 & 2.3 & 2.3 & 1.5 & 1.1 & 1.1 \\
\hline
\end{tabular}

われた $0.023 \mathrm{rad}$ ままでは、推算值と実験值がきわめてよく一致した。

\section{2 壁倍率での検証}

以上で求めた各試験体のせん断力ー変形角曲線の推算值から、壁 倍率を評価し、表 4 で実験結果から得られた值と比較した。K $2 \mathrm{P}-1$ 〜 4 では、せん断力ー変形角曲線の形状が若干異なることにより、 各決定因子の実験值と推算値に差が生じており、それに起因して壁 倍率の推算值が実験值と若干異なったが、概ね一致していると判断 できる。

A $2 \mathrm{P}$ では、純せん断部分壁体試験から得られた $\mathrm{M}_{\gamma}-\gamma$ 関係が耐 力壁の終局変位まで計測されていなかったため、途中までしか推定 することができなかった。そのため、壁倍率にかかわる一部の耐力 因子の值がかなり異なった。

\section{7、まとめ}

本論文では、耐力壁としての土壁の耐荷機構に基づいた力学モデ ルを構築し、耐荷機構の力学性状を簡易にかつ統括的に評価するた めの部分壁体試験法を考案した。そして、塗土の性質も施工の仕様 も異なる京都、滋賀、秋田の 3 種類の土壁に対して、そのせん断 カー変形角関係と壁倍率を部分壁体試験結果から推算することを試 みた。主要な成果を以下に要約する。

(1)土壁の破壊モードは、壁土のせん断破壊が先行する場合と先行し ない場合に分類でき、それぞれの破壊モードの耐力を評価するため の『部分壁体試験法』を提案した。 
壁土のせん断破壊を評価するために『純せん断部分壁体試験体』 を、また、壁土のせん断破壊が先行しない場合では、各抵抗機構の 相互作用を考慮して、1 P 耐力壁の隅角部付近と中央貫付近をそれ ぞれ切り出した『隅角部圧縮部分壁体試験体』と『貫のこじり部分 壁体試験体』を考案した。

(2)土壁の変形成分をX方向とY方向の回転及び土壁のせん断変形に 分離して、各変形成分が直列バネ配置の関係となることを示し、さ らに、各変形成分のモーメントー変形角の関係から耐力壁のせん断 カ一回転角の関係が算出できることを示した。

(3)部分壁体試験結果から、任意壁長の土壁の各変形成分に対する モーメントー変形角の関係を推算する方法を示した。

(4)仕様の異なる 3 種類の土壁に対して、耐力壁試験体と同時に製作 された部分壁体試験体の試験結果から、せん断力ー変形角関係及び 壁倍率を推算した。その結果、耐力壁のせん断力一回転角関係につ いて、最大耐力付近までは、この推算值と耐力壁試験体の実験值は 概ね一致した。

(5)耐力壁試験では壁長が長くなるに伴い、土壁はせん断破壊に移行 寸る傾向が確認された。部分壁体試験結果から、推定された破壊 モードも同様の傾向が得られた。

(6)隅角部圧縮試験体では、単調加力であったため、耐力壁とは異な る土壁の破壊性状を示したものがあり、その影響が最大耐力以降の 举動に現れた。そのため、推算值から算出された壁倍率は耐力壁の 実験結果と決定因子が異なったが、壁倍率の值は概ね一致した。 (7)以上を総括して、本論文で提案した部分壁体試験法に基づく任意 壁長の土壁耐力壁に対するせん断性状の推定方法は、その妥当性と 有用性が検証できたと考える。

\section{謝辞}

本研究の一部は、科学研究費補助金 (基盤研究 (B) (2)「塞大振動実験による新伝 統木造対震構法創成基碳技術の検証」課題番号 13450225 代表者 : 秋田県立大 学・鈴木有教授)、科学研究費補助金 (基盤研究 (A)（2）「木造軸組土壁構法に基づ く淮耐火建筑物の開発研究」 課題番号 16206060 代表者: 早稲田大学・長谷見 雄二教授)、及び科学研究費補助金 (基盤研究（C）(2）「破壊挙動に基づいた力学モ デルを応用した土壁の構造性能評価法の提案」 課題番号 16560516 代表者 : 近 畿大学・村上雅英教授)によって行われたものである。

\section{参考文献}

1) 鈴木样之、中治弘行 : 木造住宅土塗り壁の実大実験による耐震性能の再検討、 日本建築学会構造系論文集、第 519 号、pp. 115-122、1999.1

2 ) 三芳紀美子、大橋好光：土壁の強度に関寸る研究、日本建築学会大会学術講 演梗概集 構造吕、C-1、pp. 207-208、2002.8

3) 三芳紀美子、大橋好光：土壁の強度に関する研究 その 2 実大面内せん断試 験、日本建築学会大会学術講演梗概集 構造亚、C-1、pp. 409-410、2003.9 4) 濱崎信子、三芳紀美子、大橋好光 : 土壁の強度に関する研究、その 3 壁土圧 縮試験、日本建築学会大会学術講演梗概集構造III、C-1、p. 399-400、2004.8

5) 中尾方人、一文字里紗、山崎裕、石橋庸子; 土塗り壁のせん断抵抗機構および せん断耐力の評価法に関する実験的研究、日本建築学会構造系論文集、第 598 号、pp. 109-116、2005. 12

6）村上雅英、景山誠、鈴木有、稲山正弘：静的水平加力実験に基づく土壁の耐 荷機構の解明一せん断破壊しない土壁の力学挙動一、日本建築学会構造系論文
集、第 582 号、pp. 103-108、2004.8

7) 村上雅英、景山誠、岡本滋史、鈴木有、稲山正弘：要素試験による土壁の水 平力耐荷機構の検証-せん断破壊が先行しない土壁の力学挙動 (続) - 、日本建築 学会構造系論文集、第 594 号、pp. 111-118、2005. 5

8 ) 村上雅英、景山誠、岡本滋史、鈴木有、稲山正弘：水平力の耐荷機構に基づ く土壁の剛性と耐力の算定法に関する提案と検証、日本建筑学会構造系論文集、 第605号、pp. 119-126、2006.7

9）山田耕司：土壁耐力の数値解析手法の開発、日本建築学会技術報告集、第 23

号、pp. 161-164、2006. 6

10) 中尾方人、山崎裕：土塗り壁の耐力および変形性能の推定に関寸る実験的研 究(その 8 RBSMによる静的荷重増分解析)、日本建築学会大会学術講演梗概集、 C-1、pp. 241-242、2006.9

11 ) 田淵敦士、北守顕久、森拓郎、小松幸平 : 京町家型士壁の水平せん断性能、 日本建築学会構造系論文集、第605 号、pp. 143-150、2006.7

(2007年 4 月 5 日原稿受理， 2007 年 8 月 8 日採用決定 $)$ 